Pomáhajúce profesie, roč. 4, č. 1, 2021, 66-73

\title{
VZŤAH ZVLÁDANIA ZÁŤAŽE, KVALITY ŽIVOTA A ÚROVNE NEZÁVISLOSTI U PACIENTOV PO PREKONANÍ CIEVNEJ MOZGOVEJ PRÍHODY
}

\author{
Solgajová Andrea, Zrubcová Dana, Vörösová Gabriela \\ Katedra ošetrovatel'stva, Fakulta sociálnych vied a zdravotníctva, \\ Univerzita Konštantína Filozofa v Nitre \\ asolgajova@ukf.sk
}

\begin{abstract}
Abstrakt
Východiská: Hodnotenie kvality života u pacientov po prekonaní cievnej mozgovej príhody (CMP) je nevyhnutnou súčast'ou liečby. Kvalita života u pacientov po CMP súvisí s neurologickým stavom, úrovňou nezávislosti a prítomnost’ou úzkosti a depresie. Vzt'ah kvality života a adaptívnych schopnosti pacienta vyrovnat' sa so zmenami spôsobenými CMP si vyžaduje skúmanie.

Ciel: V príspevku zist'ujeme vzájomné vzt’ahy zvládania zát’aže, kvality života a funkčného stavu po prekonaní CMP.

Metódy: Išlo o prierezový typ výskumu. Celkovo bolo dotazovaných 50 hospitalizovaných pacientov po CMP, z toho 31 (62\%) mužov. Pre zber dát boli použité sebahodnotiace dotazníky Brief COPE a SF-36 a meracia škála na zhodnotenie aktivít denného života (Barthel škála ADL). Priemerný vek respondentov bol 62 rokov $(\mathrm{SD}=14,65)$. Výskum bol schválený Etickou komisiou.

Výsledky: Z adaptívnych stratégií zvládania zát’aže vykazovali s kvalitou života pozitívne štatisticky významné vzt’ahy stratégie Inštrumentálna opora, Plánovanie a Viera. Medzi úrovňou nezávislosti (ADL) a stratégiami zvládania zát’aže u pacientom po CMP neboli zistené žiadne štatisticky významné vzt’ahy. S vyššou úrovňou nezávislosti súviselo lepšie hodnotenie kvality života v oblastiach Fyzická aktivita, Bolest' a Celkové fyzické zdravie.

Implikácie: Starostlivost' o pacientov po CMP si vyžaduje komplexný model starostlivosti zahrňujúci individuálne posúdenie t’ažkostí každého jednotlivca a vytvorenie alternatívnych alebo kompenzačných opatrení pre adaptívne zvládnutie týchto t’ažkostí.
\end{abstract}

Kl'účové slová: Zvládanie zát’aže. Funkčný stav. Cievna mozgová príhoda. Kvalita života.

\section{ÚVOD}

Funkčný stav , obmedzenia v každodenných životných činnostiach, kognitívne a rečové dysfunkcie, depresia a úzkost' (Donnellan et al., 2010) sú niektoré z dôsledkov s priamym dopadom na kvalitu života pacientov po prekonaní CMP a ich rodín. Podl'a autorov Peixoto et al. (2017) kvalita života pacientov po prekonaní CMP súvisí s neurologickým stavom a úrovňou schopnosti vykonávat' aktivity denného života (ADL), ako aj s výskytom úzkosti s depresie, pričom ich predikcia je na úrovni 82 \% variability. Na základe týchto zistení autori odporúčajú poskytnút' pacientom po CMP komplexný model psychologickej starostlivosti zameranej na posúdenie t'ažkostí každého jednotlivca a na vytvorenie alternatívnych alebo kompenzačných opatrení. Autori podporujú aj dôležitost' longitudinálnych štúdií s ciel'om špecifikovat' v manažmente starostlivosti napríklad aj 


\section{Pomáhajúce profesie, roč. 4, č. 1, 2021, 66-73}

dôležitost' riešenia adaptívnych t'ažkostí pacientov so zmenami spôsobenými ochorením CMP (Robinson, Boltuc, Price, 1987).

Autori Livneh, Lott, Antonak (2004) uvádzajú, že vol'ba stratégií zvládania zát’aže predstavuje dôležitú rola pre psychosociálnu adaptáciu na postihnutie a chronické ochorenie (Livneh, Lott, Antonak, 2004). Schopnost' používat' stratégie zvládania zát’aže sú vel'mi dôležité, nakol'ko zvládanie zát’aže predpovedá pokrok v rehabilitácii (Meng et al., 2006).

Z dlhodobého hl'adiska sú u pacientov po prekonaní CMP najefektívnejšie na problém zamerané stratégie zvládania zát’aže (Donnellan et al., 2006). Naopak zvýšený psychosociálny distres je zastúpený s vyhýbavými (maladaptívnymi) stratégiami zvládania zát’aže a menej so stratégiami zameranými na riešenie problému (Donnellan et al., 2006; Finset, Andersson, 2000).

Na základe teoretickej identifikácie skúmanej problematiky a absentujúcim poznatkami v kontexte objasnenia vplyvu adaptívnych mechanizmov na kvalitu života po CMP je ciel'om príspevku zhodnotit’ vzájomné vzt’ahy zvládania zát'aže, kvality života a úrovne nezávislosti u pacientov po prekonaní CMP.

\section{METÓDY}

Celkovo výberový súbor tvorilo $\mathrm{n}=50(100 \%)$ pacientov po prekonaní CMP, hospitalizovaných na neurologickej klinike, z toho 31 (62\%) mužov a 19 (38 \%) žien. Priemerný vek u respondentov bol $\mathrm{AM}=62$ rokov $(\mathrm{SD}=14,65)$, najnižší vek bol 23 rokov a najvyšší vek bol 91 rokov. Pacienti boli dotazovaní počas hospitalizácie 72 hodín po prekonaní CMP. Z hl'adiska úrovne nezávislosti (ADL) bolo 7 (14\%) pacientov s vysokou závislost'ou, 11 (22\%) so strednou závislost'ou, 22 (44\%) s l'ahšou závislost'ou a 10 (20\%) pacientov bolo nezávislých.

Medzi zarad'ujúce kritéria výberu respondentov patrili: lekárska diagnóza CMP, lucídne vedomie, schopnost' komunikácie, schopnost’ spolupráce a vyjadrenie informovaného súhlasu s výskumom. Vylučujúcimi kritériami boli: neposkytnutie informovaného súhlasu, t’ažký klinický stav pacienta, bezvedomie, afázia, t’ažká dyzatria, pacient s jazykovou bariérou a nespolupráca pacienta.

Zvládanie zát’aže bolo hodnotené prostredníctvom sebahodnotiaceho dotazníka Brief Cope (Carver) slovenskej verzie (Baumgartner, 2001). Dotazník obsahuje 28 položiek rozdelených do 14 subškál, ktoré predstavujú stratégie zvládania zát’aže. K stratégiám zameraným na problém patrí - aktívne zvládanie, plánovanie, inštrumentálna opora, k stratégiám zameraným na emócie patrí emocionálna opora, pozitívne preformulovanie, popieranie, akceptácia, viera a humor. Stratégie zamerané na únik predstavujú ventilovanie, sebarozptýlenie, odangažované správanie, užívanie návykových látok a sebaobviňovanie. Zvládanie zamerané na problém a emócie predstavuje stratégiu adaptívnu a zvládanie zamerané na únik predstavuje stratégiu maladaptívnu. Položky sa hodnotia na štvorstupňovej stupnici: 1 - nikdy, 2 - len výnimočne, 3 - často, 4 - vždy, pričom respondenti vyjadrujú, ako sa v zátažových situáciách správali za posledných 6 mesiacov (Baumgartner, 2001).

Dotazníkom SF 36 bola hodnotená kvalita života u respondentov. Dotazník obsahuje celkom 36 položiek rozdelených do 8 dimenzií: Fyzická aktivita, Obmedzenie fyzickej aktivity, Bolest', Všeobecné zdravie, Vitalita, Spoločenská aktivita, Emocionálne problémy, Duševné zdravie. Dotazník obsahuje nezaradenú jednu položku Zdravotná zmena, ktorá nepatrí do žiadnej dimenzie. Táto položka opisuje súčasné zdravie v porovnaní so zdravím pred rokom. Ide o jednu samostatnú položku (otázku), počet možných odpovedí na ňu je 5. Položky dotazníka sú formulované tak, že vyššie skóre signalizuje lepší index HRQL (Health-Related Quality of Life). Rozmedzie celkového skóre je od 0 do 100 bodov. Skóre pod 50 môže byt' interpretované ako pod normou všeobecnej 
populácie. Nižšie skóre SF 36 signalizuje napríklad horší zdravotný stav, dlhodobé ochorenie (Ware et al., 1993; Maruish, 2011).

Úroveň nezávislosti bola u respondentov posúdená na základe použitia Barthel škály ADL (The Barthel Index of Activities of Daily Living; Mahoney, Barthel, 1955), ide o jednoduchý index nezávislosti, resp. index schopnosti pacientov s neuromuskulárnymi starat' sa o seba. Posudzuje funkčnú nezávislost' v 10-tich aktivitách denného života súvisiacich s osobnou starostlivost'ou a mobilitou: najedenie/napitie, presun lôžko-stolička-vozík, osobná hygiena, použitie toalety, kúpanie, chôdza po rovine, chôdza po schodoch, obliekanie, kontinencia moču, kontinencia stolice. Jednotlivé položky sa hodnotia v rozmedzí od 0-15, pričom celkové skóre určuje celkovo závislost' pri vykonávaní aktivít denného života: 0-40 - vysoká závislost', 45-60 stredná závislost', nad 60 závislost' l'ahšieho stupňa, nad 100 bodov nezávislost' (Bóriková, 2010).

Súhlas s realizáciou výskumu bol udelený Etickou komisiou nemocnice, kde výskum prebiehal v časovom období september 2019 - január 2020. Pre štatistické spracovanie dát bola použitá Pearsonovova korelácia (r), štatistický program IBM SPSS Statistics 21.

\section{VÝSLEDKY}

Hodnotenie vzt'ahov zvládania zát'aže bolo realizované cez rozdelenie stratégií na adaptívne a na maladaptívne stratégie zvládania zát’aže.

V prvej tabul'ke prezentujeme zistenia vzájomných vzt'ahov medzi adaptívnymi stratégiami zvládania zát’aže s kvalitou života po prekonaní CMP a úrovňou nezávislosti (ADL).

Tab. 1 Vzt’ahy adaptívnych na problém zameraných stratégií zvládania zát’aže, kvality života a úrovne nezávislosti (ADL)

\begin{tabular}{llll}
\hline & Aktívne zvládanie & $\begin{array}{l}\text { Inštrumentálna } \\
\text { opora }\end{array}$ & Plánovanie \\
\hline Fyzická aktivita & 0,199 & $0,282^{*}$ & 0,235 \\
\hline Obmedzenie fyzickej aktivity & 0,234 & $-0,074$ & 0,136 \\
\hline Bolest' & 0,120 & 0,093 & 0,048 \\
\hline Všeobecné zdravia & 0,188 & 0,228 & 0,251 \\
\hline Vitalita & 0,188 & $0,284^{*}$ & $0,321^{*}$ \\
\hline Spoločenská aktivita & 0,269 & $0,465^{* *}$ & 0,170 \\
\hline Emocionálne problémy & $-0,061$ & $-0,083$ & 0,093 \\
\hline Duševné zdravie & 0,209 & $0,299^{*}$ & 0,044 \\
\hline Zdravotná zmena & 0,089 & 0,133 & 0,194 \\
\hline Celkové fyzické zdravie & 0,262 & 0,200 & 0,249 \\
\hline Celkové psychické zdravie & 0,133 & 0,211 & 0,196 \\
\hline ADL & 0,215 & 0,107 & $-0,031$ \\
\hline
\end{tabular}

Legenda: $\mathrm{r}$ - korelačný koeficient; ${ }^{*} \mathrm{p}<0,05 ;{ }^{* *} \mathrm{p}<0,01$

V rámci analýz boli zistené viaceré štatisticky významné vzt’ahy. Adaptívna stratégia Inštrumentálna opora súvisela s nasledovnými oblast'ami kvality života: Fyzickou aktivitou ( $\mathrm{r}=$ 0 ,282); Vitalitou ( $\mathrm{r}=0,284)$; Spoločenskou aktivitou ( $\mathrm{r}=0,465)$, Mentálnym zdravím $(\mathrm{r}=0,299)$ a Celkovým psychickým stavom $(r=0,211)$. Adaptívna stratégia Plánovanie vykazovala štatisticky významné vzt’ahy s oblast'ou Vitalita $(r=0,321)$, Všeobecné hodnotenie zdravia $(r=0,251)$, 
Celkové fyzické zdravie $(r=0,249)$, Fyzická aktivita $(r=0,235)$. Žiadna adaptívna stratégia zameraná na problém nesúvisela s úrovňou nezávislosti (ADL) (tab.1).

V druhej časti analýz bol zist'ovaný vzt’ah adaptívnych na emócie zameraných stratégií zvládania zát'aže s kvalitou života a úrovňou nezávislosti (ADL).

Tab. 2 Vzt’ahy adaptívnych na emócie zameraných stratégií zvládania zát’aže, kvality života a úrovne nezávislosti (ADL)

\begin{tabular}{lllllll}
\hline & Popieranie & $\begin{array}{l}\text { Emocionálna } \\
\text { opora }\end{array}$ & $\begin{array}{l}\text { Pozitívne } \\
\text { preformulovanie }\end{array}$ & Humor & Akceptácia & Viera \\
\hline Fyzická aktivita & $-0,127$ & 0,126 & 0,249 & 0,217 & 0,153 & 0,118 \\
\hline $\begin{array}{l}\text { Obmedzenie } \\
\text { fyzickej aktivity }\end{array}$ & $-0,238$ & 0,098 & 0,067 & 0,131 & $-0,114$ & 0,022 \\
\hline Bolest' & $-0,072$ & 0,109 & 0,129 & 0,016 & $-0,113$ & 0,084 \\
\hline $\begin{array}{l}\text { Všeobecné } \\
\text { zdravie }\end{array}$ & $-0,027$ & 0,161 & $-0,114$ & 0,124 & 0,159 & $0,299^{*}$ \\
\hline Vitalita & $-0,15$ & 0,184 & 0,161 & 0,154 & 0,103 & $0,388^{* *}$ \\
\hline $\begin{array}{l}\text { Spoločenská } \\
\text { aktivita }\end{array}$ & $-0,193$ & 0,105 & 0,093 & $-0,116$ & 0,21 & 0,127 \\
\hline $\begin{array}{l}\text { Emocionálne } \\
\text { problémy }\end{array}$ & $-0,144$ & 0,136 & $-0,084$ & $-0,078$ & $-0,018$ & 0,034 \\
\hline $\begin{array}{l}\text { Duševné } \\
\text { Zdravie }\end{array}$ & 0,01 & $-0,008$ & 0,059 & $-0,068$ & 0,209 & 0,045 \\
\hline Zdravotná zmena & 0,052 & $-0,167$ & 0,111 & 0,07 & 0,029 & 0,006 \\
\hline $\begin{array}{l}\text { Celkové fyzické } \\
\text { zdravie }\end{array}$ & $-0,179$ & 0,161 & 0,163 & 0,204 & 0,064 & 0,155 \\
\hline $\begin{array}{l}\text { Celkové } \\
\text { psychické }\end{array}$ & & & & & & \\
zdravie & $-0,164$ & 0,154 & 0,03 & $-0,046$ & 0,124 & 0,172 \\
\hline \begin{tabular}{l} 
ADL \\
\hline
\end{tabular} & 0,022 & 0,054 & 0,036 & 0,031 & $-0,006$ & 0,073 \\
\hline
\end{tabular}

Legenda: $\mathrm{r}$ - korelačný koeficient; ${ }^{*} \mathrm{p}<0,05 ;{ }^{* *} \mathrm{p}<0,01$

V rámci analýz boli zistené štatisticky významné vzt'ahy iba so stratégiou Viera, ktorá súvisela s oblast'ou kvality života Vitalita $(r=0,388)$ a Všeobecným zdravím $(r=0,299)$. Žiadna z adaptívnych stratégií na emócie zameraných nesúvisela s úrovňou nezávislosti (ADL) (tab.2).

V d’alšom kroku predstavujeme analýzy vzájomných vzt’ahov maladaptívnych stratégií zvládania zát’aže, kvality života a úrovne nezávislosti (ADL). 
Tab. 3 Vzt’ahy maladaptívnych stratégií zvládania zát’aže, kvality života a úrovne nezávislosti (ADL)

\begin{tabular}{lllll} 
Sebarozptýlenie & $\begin{array}{l}\text { Odangažované } \\
\text { správanie }\end{array}$ & $\begin{array}{l}\text { Ventilo- } \\
\text { vanie }\end{array}$ & $\begin{array}{l}\text { Užívanie } \\
\text { návykových l. }\end{array}$ & $\begin{array}{l}\text { Sebaobvi } \\
\text {-ňovanie }\end{array}$ \\
\hline
\end{tabular}

\begin{tabular}{|c|c|c|c|c|c|}
\hline $\begin{array}{l}\text { Fyzická } \\
\text { aktivita }\end{array}$ & 0,227 & $-0,075$ & $0,279^{*}$ & 0,1 & 0,227 \\
\hline $\begin{array}{l}\text { Obmedzenie } \\
\text { fyzickej } \\
\text { aktivity }\end{array}$ & $0,282^{*}$ & $-0,174$ & 0,143 & 0,034 & 0,026 \\
\hline Bolest' & $0,411^{* *}$ & $-0,074$ & 0,154 & $-0,087$ & 0,178 \\
\hline $\begin{array}{l}\text { Všeobecné } \\
\text { zdravie }\end{array}$ & $-0,003$ & $-0,293^{*}$ & $0,423^{* *}$ & 0,067 & 0,162 \\
\hline Vitalita & 0,205 & $-0,096$ & $0,357^{*}$ & 0,169 & $0,297^{*}$ \\
\hline $\begin{array}{l}\text { Spoločenská } \\
\text { aktivita }\end{array}$ & 0,24 & $-0,23$ & $0,314^{*}$ & $-0,032$ & 0,192 \\
\hline $\begin{array}{l}\text { Emocionálne } \\
\text { problémy }\end{array}$ & 0,116 & $-0,098$ & 0,043 & $-0,008$ & $-0,004$ \\
\hline $\begin{array}{l}\text { Duševné } \\
\text { zdravie }\end{array}$ & $0,396^{* *}$ & $-0,249$ & 0,189 & $-0,068$ & $-0,04$ \\
\hline $\begin{array}{l}\text { Zdravotná } \\
\text { zmena }\end{array}$ & 0,125 & $-0,133$ & $-0,056$ & $-0,045$ & 0,191 \\
\hline $\begin{array}{l}\text { Celkové } \\
\text { fyzické } \\
\text { zdravie }\end{array}$ & $0,298^{*}$ & $-0,184$ & $0,331^{*}$ & 0,072 & 0,204 \\
\hline $\begin{array}{l}\text { Celkové } \\
\text { psychické } \\
\text { zdravie }\end{array}$ & $0,305^{*}$ & $-0,211$ & 0,248 & 0,017 & 0,105 \\
\hline ADL & 0,181 & $-0,029$ & 0,001 & $-0,142$ & $-0,136$ \\
\hline
\end{tabular}

Legenda: $\mathrm{r}$ - korelačný koeficient; ${ }^{*} \mathrm{p}<0,05 ;{ }^{* *} \mathrm{p}<0,01$

Podl'a zistení maladaptívna stratégia Sebarozptýlenie štatisticky významne súvisela s oblast'ou kvality života Obmedzenie fyzickej aktivity $(r=0,282)$, Bolest' $(r=0,411)$, Mentálne zdravie $(r=$ $0,396)$ a Celkové fyzické a psychické zdravie. Maladaptívna stratégia Odangažované správanie negatívne súvisela s oblast'ou Všeobecné zdravie $(r=-0,293)$. Ventilovanie ako maladaptívna stratégia pozitívne súvisela s Fyzickou aktivitou $(\mathrm{r}=0,279)$, Všeobecným zdravím $(\mathrm{r}=0,423)$, Vitalitou $(r=0,357)$, Spoločenskou aktivitou $(r=0,314)$ a Celkovým fyzickým zdravím $(r=0,331)$. Maladaptívna stratégia Sebaobviňovanie súvisela iba s oblast'ou Vitalita ( $r=0,297)$. Žiadna z maladaptívnych stratégií nesúvisela s úrovňou nezávislosti (ADL) (tab.3).

Poslednou analýzou bolo zhodnotenie vzájomného vzt’ahu úrovne nezávislosti (ADL)

a kvality života, pričom bolo zistené, že funkčný stav (ADL) u pacientov po CMP vykazoval vzájomný vzt’ah v rámci kvality života s Celkovou fyzickou aktivitou ( $\mathrm{r}=0,399)$, Bolest'ou ( $\mathrm{r}=$ $0,304)$ a Celkovým fyzickým zdravím ( $\mathrm{r}=0,335)$. 


\section{DISKUSIA}

Hodnotenie kvality života býva odporúčané v starostlivosti o pacientov po prekonaní CMP ako jedným z dôležitých prvokov v liečbe a starostlivosti. Podl'a zistení viacerých autorov súvisí kvalita života pacientov po prekonaní CMP s neurologickým stavom, úrovňou schopnosti vykonávat' aktivity denného života (ADL), s výskytom úzkosti s depresie (Peixoto et al., 2017; Donnellan et al., 2010).

Podl'a uvedenia Peixoto et al. (2017) doména kvality života Fyzický stav bola predikovaná v 78,6\% neurologickým stavom (NIHSS), úrovňou nezávislosti, kognitívnym stavom a predchádzajúcou CMP. Podla našich zistení úroveň nezávislosti (ADL) u pacientov po CMP súvisí s hodnotením domén Celková fyzická aktivita a Celkové fyzické zdravie, čím ich zistenia podporujeme.

Autori Gunaydin et al. (2011) uvádzajú, že kvalita života pacientov po prekonaní CMP je horšia ako kvalita bežnej populácie, pričom najhoršie hodnotenou oblast'ou kvality života je produktivita (fyzická aktivita/obmedzenie fyzickej aktivity), a najviac súvisí s funkčným stavom a úrovňou depresie.

V tomto kontexte autori Darlington et al. (2007) uvádzajú, že nielen vplyv funkčného stavu ale aj psychosociálny stav má tiež vplyv na hodnotenie kvality života, nakol'ko pacienti s minimálnym telesným postihnutím alebo bez telesného postihnutia vyjadrujú zníženú kvalita života. Preto sa predpokladá, že by aj d'alšie faktory mohli ovplyvňovat' kvalitu života u pacientov po CMP.

Autori Peixoto et al. (2017) uvádzajú, že medzi faktory ovplyvňujúce kvalitu života pacientov po CMP sú depresia a úzkost', pričom depresia súvisela s kognitívnou doménou kvality života, a spolu s úzkost'ou aj s doménou Emocionálne problémy. Ďalej uvádzajú, že úzkost' ovplyvňovala doménu Fyzickej aktivity a Spoločenského a rodinného života (Peixoto et al., 2017). Výskyt úzkosti a depresie sa spája v kontexte používania vyhýbavých maladaptívnych stratégií zvládania zát’aže a menej so stratégiami zameranými na riešenie problému (Donnellan et al., 2006; Finset, Andersson, 2000). Našimi zisteniami môžeme konštatovat', že najmä maladaptívna stratégia Odangažované správanie negatívne súvisela s oblast'ou Všeobecné zdravie, čo znamená, že pri jej preferovaní odangažovaného správania pacientmi je táto doména kvality života hodnotená horšie.

Adaptívne stratégie zvládania zát'aže vykazovali pozitívne vzt’ahy s viacerými doménami kvality života. Adaptívna stratégia Inštrumentálna opora súvisela s Fyzickou aktivitou, Vitalitou, Spoločenskou aktivitou, Duševným zdravím a Celkovým psychickým zdravím.

Adaptívna stratégia Plánovanie súvisela s oblast'ou Vitalita, Všeobecné zdravie, Celkové fyzické zdravie, Fyzická aktivita. Išlo o adaptívne na problém zamerané stratégie zvládania zát’aže, ktoré sú z dlhodobého hl'adiska u pacientov po prekonaní CMP najefektívnejšie (Donnellan et al., 2006). S adaptívnou stratégiou (na emócie zamerané zvládania zát’aže) Viera pozitívne súvisela oblast' kvality života Vitalita a V̌̌eobecné zdravie.

Autori Rachpukdee et al. (2013) popisujú, že sociálna opora súvisí s úrovňou nezávislosti a vyššia úroveň nezávislosti sa spájala aj s lepším hodnotením kvality života u pacientov po CMP. Podl'a našich zistení, žiadna stratégia zvládania zát’aže nesúvisela s úrovňou nezávislosti (ADL).

Podl'a vyjadrenia autorov Rachpukdee et al. (2013) aj po troch mesiacoch po prekonaní CMP sa pacienti vyrovnávajú s psychosociálnym stresom, pričom zlepšenie sa viac javí vo fyzickej doméne ako v duševnej doméne, preto je dôležité v liečbe zahrnút' starostlivost' o fyzické aj duševné aspekty ochorenia CMP. Pre zlepšenie odporúčajú holistický rehabilitačný program. 


\section{ZÁVER}

Hodnotenie kvality života u pacientov po prekonaní cievnej mozgovej príhody (CMP) je nevyhnutnou súčast'ou liečby. Úroveň nezávislosti (ADL) súvisí s hodnotením kvality života (celkovou fyzickou aktivitou a celkovým fyzickým zdravím). Adaptívne stratégie zvládania zátaže pozitívne korelovali s kvalitou života. Medzi úrovňou nezávislosti (ADL) a stratégiami zvládania zát’aže u pacientom po CMP neboli zistené žiadne štatisticky významné vzt’ahy.

Starostlivost' o pacientov po CMP si vyžaduje komplexný model starostlivosti zahrňujúci individuálne posúdenie t’ažkostí každého jednotlivca a vytvorenie alternatívnych alebo kompenzačných opatrení pre adaptívne zvládnutie týchto t’ažkostí.

\section{LITERATÚRA}

Baumgartner, F. (2001). Zvládanie stresu - coping. In J. Výrost , I. Slaměník (Eds.). Aplikovaná sociální psychologie II. Praha : Grada, 2001, s. 191-208.

Bóriková, I. (2010). Posudzovanie aktivít denného života. Ošetřovatelství a porodní asistence, 1(1), 24-30.

Darlington, A., S., Dippel, D., W., Ribbers, G., M., van Balen, R., Passchier, J., \& Busschbach, J., J. (2007). Coping strategies as determinants of quality of life in stroke patients: a longitudinal study. Cerebrovascular Diseases, 23(5-6), 401-407. doi: 10.1159/000101463.

Donnellan, D., Hevey, A., Hickey, D., \& O’Neil, L. (2006). Defining and quantifying coping strategies after stroke: a review. Journal of Neurology, Neurosurgery, and Psychiatry, 77(3), 1208-1218.

Donnellan, C., Hickey, A., Hevey,D. \& O’Neill, D. (2010). Effects of mood symptoms on recovery one year after stroke. International Journal of Geriatric Psychiatry, 25(12), 1288-1295.

Finset, A., \& Andersson, S. (2000). Coping strategies in patients with acquired brain injury: relationships between coping, apathy, depression and lesion location. Brain Injury, 14(2), 887-905.

Gunaydin, R., Karatepe, A., G., Kaya, T., \& Ulutas, O. (2011). Determinants of quality of life (QoL) in elderly stroke patients: A short-term follow-up study. Archives of Gerontology and Geriatrics, 53, 19-23. doi: 10.1016/j.archger.2010.06.004.

Livneh, H., Lott, S., M., \& Antonak, R., F. (2004). Patterns of psychosocial adaptation to chronic illness and disability: a cluster analytic approach. In Psychology, Health \& Medicine, 9(2), 411-430.

Mahoney, F., I., \& Barthel, D., W. (1965). Functional evaluation: The Barthel Index. Maryland State Medical Journal, 14(2), 61-65.

Maruish, M. E. (Ed.) (2011). User's manual for the SF-36v2 Health Survey (3rd ed.). Lincoln, RI: QualityMetric Incorporated.

Meng, K., Zdrahal-Urbanek, J., Frank, S., Holderied, A., \& Vogel, H. (2006). Patients' expectations, motivation and multi-dimensional subjective and objective socio-medical success in medical rehabilitation measures. International Journal of Rehabilitation Research, 29(1). 65-69. doi: 10.1097/01.mrr.0000185955.33046.fd.

Peixoto, B., Silvac, S., Carreirad, S., Sousae, D., Rezendef, V., \& Teixeiraf, A. (2017). Quality of life predictors after first stroke: A study with post-acute patients. Neurology, Psychiatry and Brain Research, 23, 10-15.

Rachpukdee, S., Howteerakul, N., Suwannapong, N., \& Tang-aroonsin, S. (2013). Quality of Life of Stroke Survivors: A 3-Month Follow-up Study. Journal of Stroke and Cerebrovascular Diseases, 22(7), e70-e78. https://doi.org/10.1016/j.jstrokecerebrovasdis.2012.05.005. 
Robinson, R. G., Bolduc, P. L., \& Price, T. R. (1987). Two-year longitudinal study of poststroke mood disorders: Diagnosis and outcome at one and two years. Stroke, 18(5), 837-843.

Ware, J. E., Jr., Snow, K. K., Kosinski, M., \& Gandek, B. (1993). SF-36 Health Survey manual and interpretation guide. Boston, MA: The Health Institute.

\title{
RELATIONSHIP BETWEEN COPING, QUALITY OF LIFE AND FUNCTIONAL STATUS IN PATIENTS AFTER STROKE
}

\begin{abstract}
:
Background: Evaluation of quality of life in patients after stroke is an essential part of treatment. Quality of life in patients after stroke is related to neurological status, functional status, and the presence of anxiety and depression. The relationship between patient's quality of life and adaptive copeing with changes caused by stroke requires research.

Aim: Relationships between coping, quality of life and functional status after stroke are studied.

Methods: A cross-sectional type of research wasa used. Total of 50 hospitalized patients after stroke were interviewed, of which 31 (62\%) were men. Brief COPE and SF-36 self-assessment questionnaires and (Barthel ADL) scale for evaluating daily life activities were used for data collection. The average age of the respondents was 62 years ( $S D=14.65)$. The research was approved by the Ethics Committee.

Results: Of the adaptive coping strategies, the Strategic Support, Planning and Faith strategies showed positive statistically significant relationships with quality of life. No statistically significant relationships were found between functional status (ADL) and coping strategies in patients after stroke. Higher level of functional status was associated with better quality of life in the areas of Physical Activity, Pain and General Physical Health.

Implications: Patient care after stroke requires a comprehensive model of care that includes an individual assessment of each individual's difficulties and the development of alternative or compensatory strategies to adaptively cope with these difficulties.
\end{abstract}

Keywords: Coping. Functional status. Stroke. Quality of life.

\section{Grantová podpora:}

Príspevok bol podporený projektom VEGA 1/0418/19 Zvládanie zát’aže v procese rekonvalescencie po cievnej mozgovej príhode. 